\title{
Bio-regenerative rating technique: a critical review
}

\author{
M. A. Hanafi \& M. M. Naguib \\ Department of Architecture, Faculty of Engineering, \\ University of Alexandria, Egypt
}

\begin{abstract}
Since the energy crisis in the 1970s, there has been a rising concern to energy efficiency and the influence of building on the natural environment and thus, innovative architectural designs should satisfy the natural environmental desires as much as the client's desires. Bio-Eco Architecture harnesses and replicates the principles found in nature in order to create built environments which benefit people and other living creatures as well as safe-guarding the biodiversity of the environment. Biomimetics in architecture will help develop a culture of active environmental design. This paper represents a comparative critical revision of five selected checklists aiming to reflect the changes in attitude that have affected sustainable design in the past 15 years as well as to combine all these concepts of sustainability for achieving the most helpful example which will not only help in creating a healthy environment but will also produce positive environmental impacts. It has been commonly noted that the main perception of nature influenced forms is basically aesthetic while little concern is given to the importance of inspiring from nature in the construction and structural performance of buildings, thus, this paper will present a comprehensive analysis of the roles that bio-inspiration (inspiring architectural form, function and construction process from natural organisms) plays in developing the concept of sustainable, ecological design and construction in contemporary architecture. This paper will discuss the significance of quantitative rating systems and checklists which could be applied to a technological worldview and are inappropriate for living system understanding and adaptation, thus, a better understanding of biological morphogenesis can usefully inform architectural
\end{abstract}


designing which aims to resolve challenges that have often already been resolved by nature.

Keywords: biomimetics, wilderness and regenerative based checklist, living building certification, biophilic design, LEED, inspiration from nature.

\section{Introduction}

Over many years of human intervention natural sites are unfortunately alerted by the act of building. "Green" or "sustainable" buildings can be characterized as buildings with a conscious effort to minimize their negative impacts on the environment as well as encouraging positive environmental and social impact of buildings. The UNEP [United Nations Environment Programme] and IUCN [International union For Conservation of Nature] also describe sustainable development as: "Improving the quality of human life while living within the carrying capacity of supporting ecosystems" [1].

It was 30 years ago when an architect (Malcolm Wells) authored a simple guide for design and construction of ecological green shelter in 1969 which was called the Wilderness-Based Checklist for Design and Construction. This checklist was the key concept for the leadership in energy and environmental design (LEED), in 1998. Wells' original checklist has been updated slightly during the summer of 1999 by the society of building science educators (SBSE) and is now referred to as the Regeneration-Based Checklist for Design and Construction. Natural analogies or biomimicry offer numerous inspirational lessons, they provide examples of how designing with nature can produce more effective, regionally sensitive and energy efficient buildings. Thus, Kellert [in his book building for life 2005] developed a set of biophilic standards checklist as he believes that "people don't live by efficiency alone". Low impact design as exemplified by LEED standards rarely enhances people's physical and mental well being. In a further effort to create an advanced checklist that aims to achieve net-zero building impact, a step above LEED platinum but below regenerative design, the Cascadia Region Green building council had launched the living building certification program (LBC) in 2006.

Thus, this paper represents a comparative critical revision of the above five checklists in order to reflect the changes in thinking that have affected sustainable design in the past 15 years as well as to combine all these concepts of sustainability to achieve the most efficient example which will not only help in creating a healthy environment without any harmful effects but will also have a positive environmental and social impacts.

\section{General review of selected sustainable rating systems}

The following represents a moderate revision of most applicable green rating systems in today's market as well as reviewing the old concept of regenerative checklists in order to create a comparative table aiming at exploring new concepts of bio-regenerative design. 


\subsection{The wilderness-based checklist for design and construction, 1969}

Malcolm wells has provided leadership in designing with nature as he suggests a way to test designs by using an array of criteria developed from an analogy with a natural system. His checklist consists of 15 items that measures various criteria. Each issue can be rated on a scale from "poor -100 " to "good +100 " with levels in between. In wells opinion, wilderness scores a perfect +1500 .

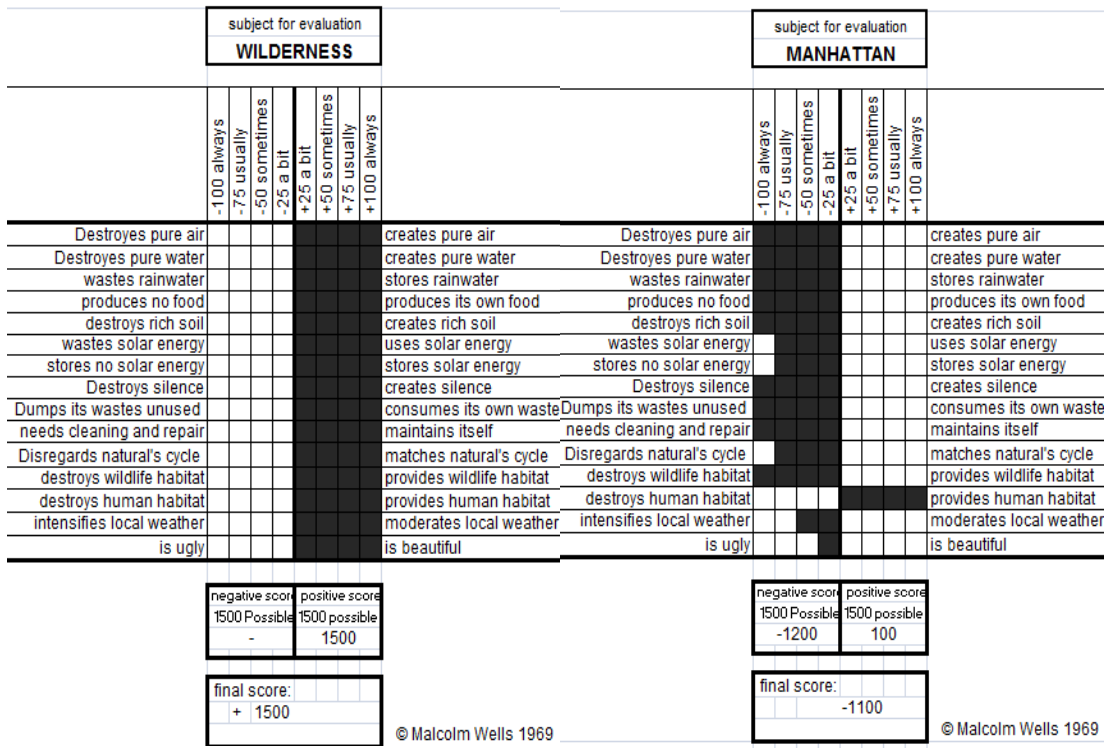

Figure 1: Comparison between the purities and impurities of wilderness and cities (source: Wells [3]).

The previous comparison shows how Wells sees the difference between Natural Wilderness and the dense city of Manhattan as he passionately expressed "Architecture is the outward expression of a way of life and as such, it must begin to express real reverence for life, actually helps support life. Our value criteria are so unstable that nothing can be objectively compared with anything but there is a way to evaluate what designer do. There's a stable and very simple scale on which one work can be rated versus another, So far as we know, the only fully appropriate structures and the only truly successful communities ever to be established were those myriad miracles that we now lump together under the word (wilderness), they can be used as an unchanging standard against which we can measure our own solutions" [3].

The wilderness and city have exactly the same goal which is the need of a successful living community on the land. The shameful cities of today have only one treasure, to human eye, which is people-human beings and human resources; culture; the arts and the sciences. The rest of the city is pure failure.That's why 
it's so important to recognize the value of the lessons the wilderness offers and the need to apply them right now [3].

\subsection{The regeneration-based checklist for design and construction, 1999}

The society of building science educators (SBSE) organized considerations for sustainable design and construction into two categories, Site and Building. Elements within each group, such as energy use and air quality, are then graded based on whether they are (regenerative) positive score which gives back to the environment or (degenerative) negative score illustrates the ecological damage done by ignoring concerns of sustainability. A sum of zero achieves sustainability. There's no gold or platinum score in this checklist, just a healthy built environment and a happy planet [10].

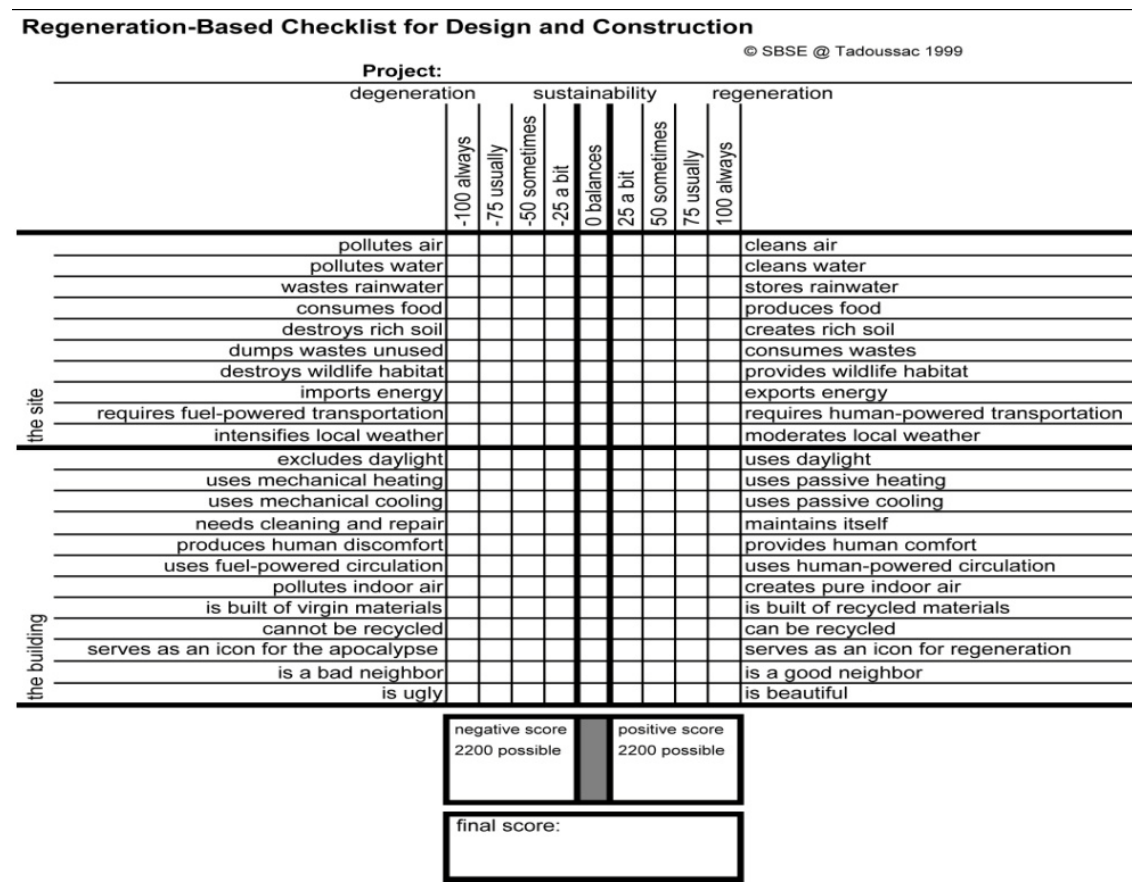

Figure 2: Regenerative based checklist for design and construction (source: McClure and Bartuska [10]).

Wells and the sbse group explored the variabiles of an integrated, sustainable systems to design an approach that emphasizes the dynamic, symbiotic integration of human-environmental, ecological processes of the earth. This aproach has come to be known as "Sutainable Systems and Regenerative Design (SS/RD)" which emphasize that the comprehensive set of factores discussed are not stand-alone, static variables but rather interactive parts of a dynamic biological/ecological system [10]. 
Regenerative design is a form of sustainable design which incorporates the interlocking of communities with the natural ecological cycles, the larger society and environmental costs. The overall goals for regenerative developments are to design communities which exist within natural limits and are interconnected to the regional society for needs outside the given site. Regenerative design incorporates diverse ecological, cultural, social and economical systems while maintaining their integrity within a dynamic whole [5].

\subsection{LEED checklist}

Current sustainable design is measured based on prescriptive standards like LEED (and other equivalents green rating systems) aiming to minimize the bad impact of the built environment which harm the natural environment and responsible for destroying it over time and also aiming to enable buildings for being recognized according to their environmental benefits, to stimulate demand for sustainable buildings, as well as to allow organizations to demonstrate progress towards corporate environmental objectives.
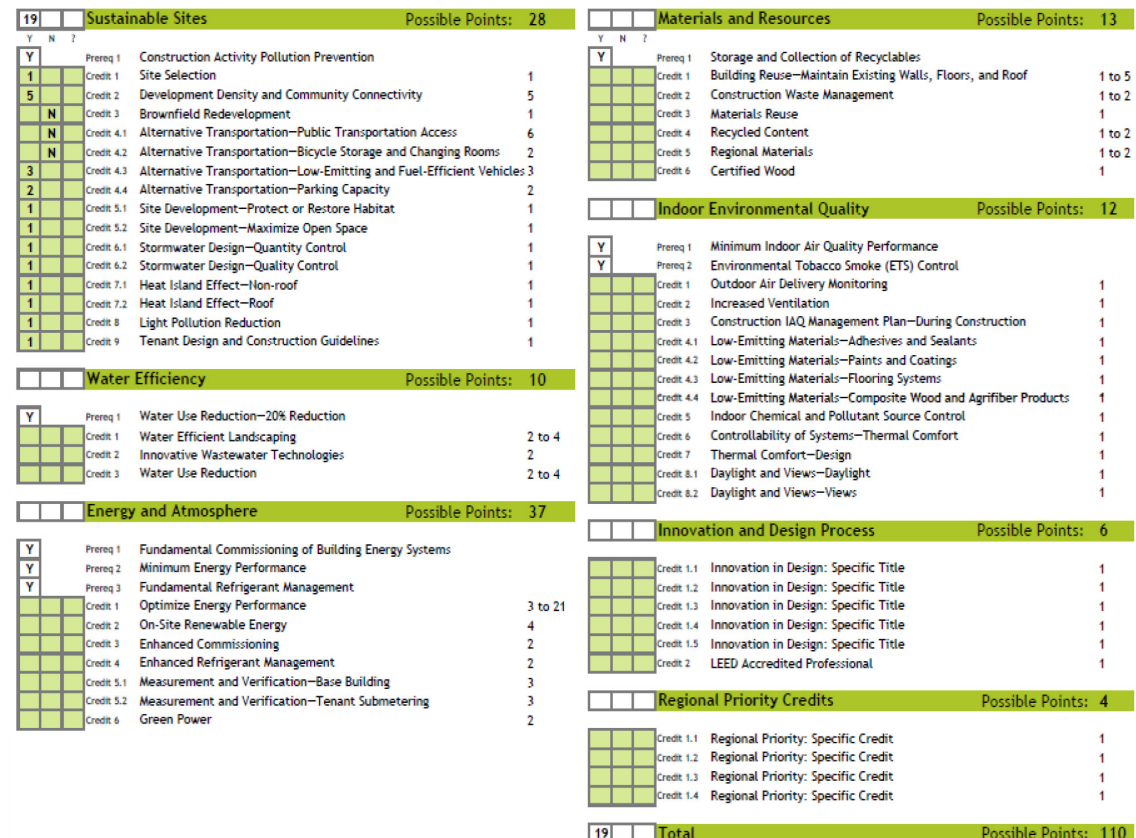

Figure 3: LEED checklist Source: LEED Green Associate Study Guide, retrieved 10-1-2012.

LEED (Leadership in Energy and Environmental Design) certification contains a set of measurable standards that collectively identify whether a development or proposed development of one more buildings can be deemed 
environmentally superior, considering its use of green technology and building techniques and many other aspects. These standards include prerequisites (required as a baseline for sustainable design) with points accumulated from many optional credits, LEED has worked well in part because its standards are clear and objectively measurable, and the results of meeting LEED standards are visible in employee health, energy costs, and resource use [9].

\subsection{Biophilic standards checklist}

Kellert (in his book Building for Life 2005) believes that the prelevant approach to sustainability is to look at nature and how it adapts itself without harming the ecosystem and while recognizing the significance of "LEED" he argues that "people don't live by efficiency alone". Low impact design as exemplified by LEED standards rarely enhances people's physical and mental well being as he also says: "By ignoring the human need to connect with nature and place, low impact designs are often experientially and aesthetically deficient" [2].

\begin{tabular}{|l|l|l|}
\hline \multicolumn{3}{|c|}{ Attributes of Biophilic Design } \\
\hline $\begin{array}{l}\text { Environmental } \\
\text { Features }\end{array}$ & $\begin{array}{l}\text { Natural shapes } \\
\text { \& forms }\end{array}$ & $\begin{array}{l}\text { Natural pattern } \\
\text { \& process }\end{array}$ \\
\hline Natural materials & Botanical motifs & Sensory Variability \\
\hline Natural colors & Animal motifs & Information richness \\
\hline Water & Shell \& spiral forms & Age,change \\
\hline Air & Egg, ovular form & Growth \\
\hline Sunlight & Arches, vaults, domes & Central focal point \\
\hline Plants & Tree \& columnar supports & Patterned whole \\
\hline Animals & Shapes lacking right angles & bounded spaces \\
\hline Natural views & Simulation of natural system & transitional spaces \\
\hline Facade greening & Resemblance to natural features & Linked series \& chains \\
\hline Geology \& landscape & Geomorphology & $\begin{array}{l}\text { integration of parts to } \\
\text { wholes }\end{array}$ \\
\hline Habitat \& ecosystem & $\begin{array}{c}\text { Mimicking organic } \\
\text { function-biommicry }\end{array}$ & $\begin{array}{l}\text { similar format differ } \\
\text { encale-fractals }\end{array}$ \\
\hline Fire & & $\begin{array}{l}\text { dynamic balance \& ten- } \\
\text { slon } \\
\text { complementary contrasts }\end{array}$ \\
\hline & & $\begin{array}{l}\text { hierarchically organized } \\
\text { scales }\end{array}$ \\
\hline
\end{tabular}

\begin{tabular}{|c|c|c|}
\hline Light \& space & place connections & $\begin{array}{l}\text { evolved relation } \\
\text { to nature }\end{array}$ \\
\hline Natural Light & $\begin{array}{l}\text { geographical con- } \\
\text { nectin place }\end{array}$ & prospect \& refuge \\
\hline $\begin{array}{l}\text { filtered \& diffused } \\
\text { light }\end{array}$ & $\begin{array}{l}\text { Historical connec- } \\
\text { tion place }\end{array}$ & order \& complexity \\
\hline light \& shadow & $\begin{array}{l}\text { cultural connec- } \\
\text { tion place }\end{array}$ & $\begin{array}{l}\text { enticement \& curi- } \\
\text { osity }\end{array}$ \\
\hline reflected Light & $\begin{array}{l}\text { ecological connec- } \\
\text { tion place }\end{array}$ & $\begin{array}{l}\text { change \& metamor- } \\
\text { phosis }\end{array}$ \\
\hline Light pools & $\begin{array}{l}\text { indigenous materi- } \\
\text { als }\end{array}$ & $\begin{array}{l}\text { Affection \& attach- } \\
\text { ment }\end{array}$ \\
\hline warm light & $\begin{array}{l}\text { landscape orienta- } \\
\text { tion }\end{array}$ & Attraction \& beauty \\
\hline $\begin{array}{l}\text { Light as shape \& } \\
\text { form }\end{array}$ & landscape ecology & $\begin{array}{l}\text { Exploration \& dis- } \\
\text { covery }\end{array}$ \\
\hline spaciousness & $\begin{array}{l}\text { integrating culture } \\
\text { \& ecology }\end{array}$ & Fear $\&$ awe \\
\hline spatial variability & $\begin{array}{l}\text { sence or spirit of } \\
\text { place }\end{array}$ & $\begin{array}{l}\text { Information \& un- } \\
\text { derstanding }\end{array}$ \\
\hline $\begin{array}{l}\text { space as shape \& } \\
\text { form }\end{array}$ & $\begin{array}{l}\text { avoiding placeless- } \\
\text { ness }\end{array}$ & Mastery \& control \\
\hline $\begin{array}{l}\text { spatial integration } \\
\text { of lightness }\end{array}$ & $\begin{array}{l}\text { landscape features } \\
\text { that define build- } \\
\text { ing form }\end{array}$ & $\begin{array}{l}\text { security \& protec- } \\
\text { tion }\end{array}$ \\
\hline $\begin{array}{l}\text { Inside \& outside } \\
\text { spaces }\end{array}$ & & $\begin{array}{l}\text { Reverence \& spiritu- } \\
\text { ality }\end{array}$ \\
\hline
\end{tabular}

Figure 4: Biophilic standards checklist (source: Kellert [2]).

In an effort to create restorative and regenerative design Kellert developed a set of biophilic standards checklist based on 6 elements and 75 attributes, calling it "A pattern language to help people who want a checklist". According to Kellert, biophilic design has to make sense in context and must make sense culturally. Biophilic standards checklist provides a base to design in harmony with nature but don't offer a meaningful Bio-Eco regenerative checklist.

\subsection{The living building checklist (LBC)}

According to leading biomimetic thinker Bill Reed: (who co-chaired the development of LEED standards from the outset): "We could have a world full of LEED platinum buildings and still destroy the planet, these greener designs, 
though progressive, often stick too close to the existing standard in a way that is simply "less bad" [7].

According to Jason McLennan, AIA: (Living Building Challenge Creator and Cascadia CEO):"A world full of typical green buildings doesn't get us where we need to be to avoid environmental catastrophe" [6].

So, it was believed that a LEED certification is not enough for a better healthy regenerative environment, thus, systems and strategies are needed to avoid environmental catastrophe. Consequently, the living building certification (LBC) has been established in 2006 by the International Living Future Institute grew out of the Cascadia Region Green Building Council which certifies the World's Greenest Buildings aiming to recognize buildings meeting the highest level of sustainability [7].

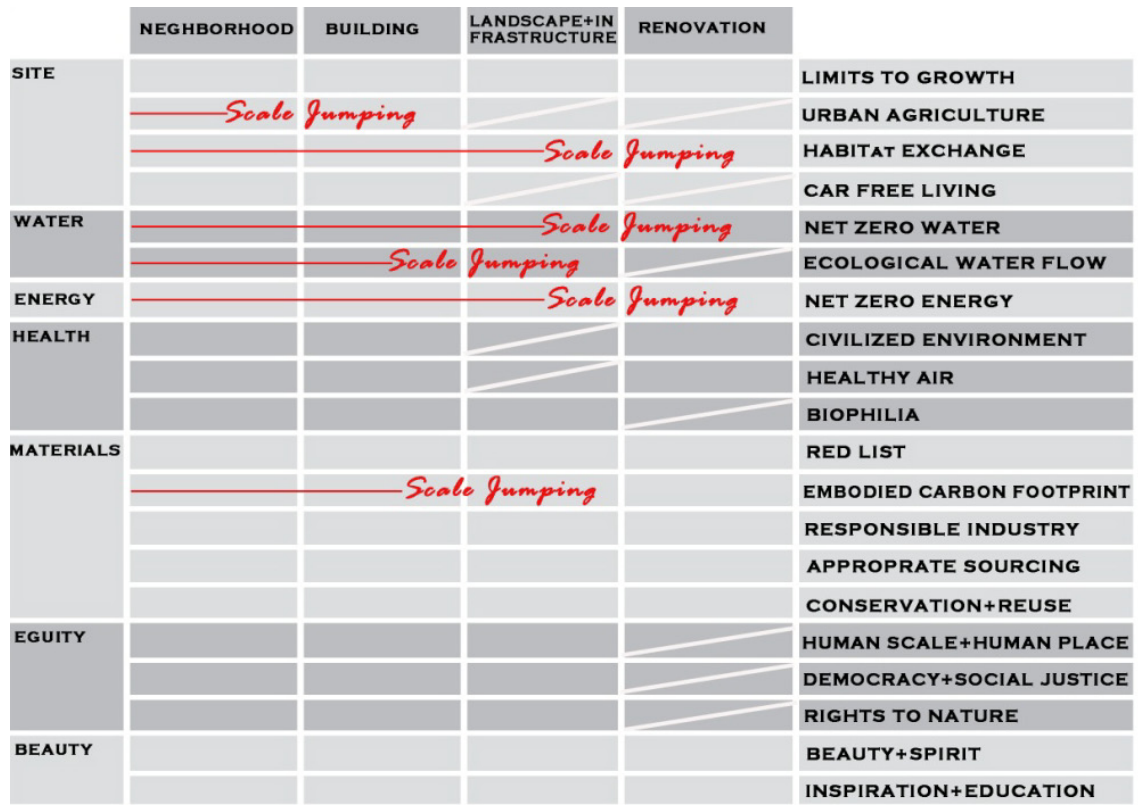

Figure 5: Living building certification checklist (source: www.ilbi.org, retrieved 15-1-2012).

The main strategy of this rigorous certification is to contribute to the ecosystem, emulating the natural systems of the world by pushing architects to think not about doing less harm to the earth, but about doing no harm and even restore the environment. At a minimum, LBC projects aim to achieve a net-zero building impact, a step above LEED Platinum but below regenerative design, in which a building would give more back to the earth in terms of ecological services than it takes away. From there a project can either be regenerative or restorative. Buildings must meet stringent site requirements, achieve net-zero energy and water use, avoid the system's red-listed materials, and source materials locally. A project not only must require no recourse to renewable 
energy, but it should give back to the local community and/or eco-system. One of the main differences between LBC and LEED is being based solely on actual recorded performance. A project cannot be granted a Living Building Challenge certificate for at least a year after completion to properly monitor energy use and occupant behaviour. Achieving LBC Certification, with all prerequisites and no complicated credits and points (In contrast to most other rating systems, including LEED, with points accumulated from many optional credits) is difficult but not impossible. LBC has 16 prerequisites divided into a half dozen categories (called "petals"). Project teams can choose whether to pursue all of the prerequisites and achieve full certification or pursue one or two petals and be recognized for leadership in specific areas. In both cases the requirements for each prerequisite are all or nothing. The system is not designed to measure or even rate buildings in the traditional sense but it is intended to change the way of designing and to transform the way code officials and manufacturers think about buildings and products. The rating system looks relatively simple but behind the apparent simplicity are nuances that deal with the reality of current market conditions in the form of a variety of exceptions particularly those involving materials and water. These exceptions are granted when a team is unable to meet one of LBC's requirements despite significant effort. The exceptions make LBC possible in today's market conditions as McLennan noted:"It may be bloody hard, but it's achievable" [6].

\section{A critical analysis of the previous checklists}

Although, green architecture is much more than one that is conserving energy and minimizing pollution, many green rating system approaches are used to show "false positive", this is because the concept of green building in contemporary usage is intended to imply buildings above and beyond minimum code requirements with the primary focus and intent being to protect the environment. It is important to note that being rated does not mean a building has no negative impact on the environment.

Some critics of LEED rating system have concluded that "there is evidence that society is not using LEED as guideline to reduce ecological impact, but rather as an asset for positive publicity" [4].

Other critics have pointed out that the application of rating systems are very subjective process with few criteria which are truly measurable. Further criticism define rating system is based on checking certain components on the building without assessing the ability of the building to continue providing outstanding service for the future. For example, a sustainable proposed development could have landscape roofs, geothermal energy production, photovoltaic panels, high performance window and extensive use of recycled and renewable materials, but be a hulking structure, out of scale with the neighbourhood. This cannot be taken to state that green buildings methodologies are unsustainable, but it does suggest that vital point has been missed in current green building thinking and practice. 


\subsection{What is missing in current green building thinking?}

The missing vital points in green building thinking could be: the sense of place and mimicking the natural organisms as well as the occupant satisfaction.

\subsubsection{Lack of sense of place}

Although, the heart of ecological design is to design with and for place, in the era of globalization, cheap and abundant energy and materials, place seems not to matter. One place seems interchangeable with another. Architects and their clients have created a 'geography of nowhere', disregarding the physical and cultural context that makes one place unique from another.

A living building in the futureshould act like all living creatures which use specialized strategies for adapting to the dynamic conditions of their environment,for exapmle, dessert plants and animals have evolved specialized strategies for adapting to the extremes of temperatures, sunlight and moisture, taking cues from these creatures, an ecologically designed desert structure might apply analogous adaptations, using the building's skin to convert sunlight into elctricity or perhaps integrating radiatiors and cooling towers with the building's communication systems. The idea is to design as nature does: optimizing systems by finding multiple funtions for each part.

\subsubsection{Lack of the occupant satisfaction and comfort}

It was 30 years ago, when psychologists and architects, [including the senior author, Van der Ryn and Silverstein, 1967] pioneered the post-occupancy evaluation of buildings in an effort to build an objective reliable database on how designed environments affect occupant's health, well being and performance. Unfortunately, architectural profession resisted this effort at objective evaluation as an infringement on professional prerogatives and institutional clients discouraged outside evaluation as a potential source of criticism of their decisions. As a consequence the majority of rating systems measure the intention of designer rather than the performance of the building. That's why there is a need to provide a satisfaction scale that can measure the satisfaction of the building occupancy in the operation stage as well as measuring the human productivity. also it should be noted that improving occupant health, Comfort, productivity, reducing pollution are not easily quantified, but it may result in sort of qualitative analysis through a post occupancy questionnaire collected during the operation of the building before it could be certified.

\section{Sustainability concept within bio-eco rating techniques}

According to the previous review some of the key concepts of any sustainable development can be classified as shown in Tables 1 and 2 .

\subsection{A comparative analysis of different sustainable checklists based on the previous classification of sustainable bio-eco regenerative rating techniques}


Table 1: Some of the key concepts of sustainable development.

\begin{tabular}{|c|c|}
\hline \multirow{3}{*}{$\begin{array}{l}\text { CREATING A CLEAN } \\
\text { ENVIRONMIENT }\end{array}$} & Clean Air \\
\hline & Clean Water \\
\hline & Clean Soil \\
\hline \multirow{7}{*}{$\begin{array}{l}\text { MIMICKING NATURAL } \\
\text { SYSTEMS IN THE WAY } \\
\text { THEY ACT FOR } \\
\text { SURVIVING OR } \\
\text { ECOMORPHISM }\end{array}$} & Store, Filtering And Re-Use Rainwater \\
\hline & Use Renewable \& Clean Energies And Store Solar Energy \\
\hline & Recycling Everything Or Consuming Its Own Waste \\
\hline & Produces Its Own Food \\
\hline & Maintains Itself \\
\hline & Minimize Materials Use While Providing High Efficiency \\
\hline & Use Local Materials \\
\hline \multirow{2}{*}{$\begin{array}{c}\text { PROTECT WILDLIFE } \\
\text { HABITAT }\end{array}$} & Habitat Exchange \\
\hline & Limits Of Growth \\
\hline $\begin{array}{c}\text { PROTECT HUMAN } \\
\text { HABITAT }\end{array}$ & Occupant Satisfaction And Comfort \\
\hline \multirow{3}{*}{ BE A GOOD NEIGHBOR } & Sense Of Place \\
\hline & Creates Silence \\
\hline & Be Beautiful And Have A Nature Inspiration \\
\hline
\end{tabular}

\section{Conclusion}

A philosophy of ecological design will eventually have profound impact on architecture and technology. In the future world will be designed to function like living organisms, specifically adapted to place and able to draw all of their requirement for energy and water from the surrounding, while the main role of the architect will be how to design an "Ecomorphic buildings" buildings that mimic natural systems and have the capacity to reconnect people to nature. A healthy environment and pure air can enhance human mental well being and by consequence will enhance human productivity. Plants are the true producer of oxygen able to absorb and ameliorate the effect of air or soil pollution. Thus, by considering the importance of creating a clean environment for all species health, architect should cooperate with agricultural, biologist and other experts in the design process of any building, so they can calculate the amount of oxygen emission per hour for each type of plant, while the architect with the biologist can calculate the amount of $\mathrm{CO}_{2}$ emission per person per hour and by this equation they should provide in the design green areas which will help the building to present a positive contribution to the natural environment. This is because if human act of the construction embodied carbon footprint could be neutralized and they could stop using materials with a voltaic organic compound emission, stop burning fossil fuel, they could never stop breathing and emitting $\mathrm{CO}_{2}$ to the environment. There is also a lack in integrating the protection of the topsoil as well as considering the importance of producing the own food of a neighbourhood in the advanced sustainable rating systems, however, it has been presented in the very early checklist of Malcolm Wells but unfortunately people don't take this point into consideration. 
Table 2: Some of the key concepts of sustainable development.

\begin{tabular}{|c|c|c|c|c|c|c|}
\hline Imperative & Dements & $\begin{array}{l}\text { The } \\
\text { Wilderness } \\
\text { Checklist }\end{array}$ & $\begin{array}{c}\text { The Regen. } \\
\text { based } \\
\text { Cheoklist }\end{array}$ & LDDD & $\begin{array}{l}\text { Bophillic } \\
\text { design } \\
\text { Checklist }\end{array}$ & LBC \\
\hline \multirow{3}{*}{$\begin{array}{l}\text { Creating } \\
\text { Clean } \\
\text { Dnviron- } \\
\text { ment }\end{array}$} & Clean Air & $\begin{array}{l}\text {-Creating } \\
\text { pure air }\end{array}$ & $\begin{array}{l}\text {-Creating } \\
\text { pure air in site } \\
\text {-Creating } \\
\text { pure indoor } \\
\text { air } \\
\text {-Requires } \\
\text { human- } \\
\text { powered } \\
\text { transportation } \\
\text {-Use human } \\
\text { powered } \\
\text { circulation }\end{array}$ & $\begin{array}{l}\text {-Low emitting } \\
\text { and fuel- } \\
\text { efficient } \\
\text { vehicles } \\
\text {-Low emitting } \\
\text { materials } \\
\text {-Indoor } \\
\text { chemical and } \\
\text { pollutant } \\
\text { source control }\end{array}$ & $\begin{array}{l}\text {-Plants } \\
\text { existence } \\
\text {-Façade } \\
\text { greening } \\
\text {-Air purity } \\
\text {-Geology and } \\
\text { landscape } \\
\text { preservation }\end{array}$ & $\begin{array}{l}\text {-Urban } \\
\text { agriculture } \\
\text {-Healthy air } \\
\text { - Offset the } \\
\text { embodied } \\
\text { carbon } \\
\text { footprint of } \\
\text { the } \\
\text { construction, } \\
\text {-Car free } \\
\text { living } \\
\text {-Red list } \\
\text { materials }\end{array}$ \\
\hline & Clean Soil & $\begin{array}{l}\text {-Creating } \\
\text { rich soil }\end{array}$ & $\begin{array}{l}\text {-Creates rich } \\
\text { soil }\end{array}$ & $\begin{array}{l}\text { - No } \\
\text { equivalent }\end{array}$ & $\begin{array}{l}\text { - No } \\
\text { equivalent }\end{array}$ & $\begin{array}{l}\text { - No } \\
\text { equivalent }\end{array}$ \\
\hline & $\begin{array}{l}\text { Clean } \\
\text { Water }\end{array}$ & $\begin{array}{l}\text {-creates } \\
\text { clean water }\end{array}$ & $\begin{array}{l}\text {-creates } \\
\text { clean water }\end{array}$ & $\begin{array}{l}\text {-Water use } \\
\text { reduction } 20 \% \\
\text { - Water } \\
\text { efficient } \\
\text { landscape } \\
\text { - Innovative } \\
\text { wastewater } \\
\text { technologies } \\
\text { - Storm water } \\
\text { design- quality } \\
\text { control }\end{array}$ & $\begin{array}{l}\text {-Water as an } \\
\text { environmenta } \\
1 \text { feature }\end{array}$ & $\begin{array}{l}\text {-Net zero } \\
\text { water } \\
\text {-The } \\
\text { ecological } \\
\text { water flow }\end{array}$ \\
\hline \multirow{3}{*}{$\begin{array}{l}\text { Mimics } \\
\text { Natural } \\
\text { Systems In } \\
\text { The Way } \\
\text { They Act } \\
\text { For } \\
\text { Surviving }\end{array}$} & $\begin{array}{l}\text { Store, and } \\
\text { Re-Use } \\
\text { Rainwater }\end{array}$ & $\begin{array}{l}\text {-Stores } \\
\text { rainwater }\end{array}$ & $\begin{array}{l}\text {-Stores } \\
\text { rainwater }\end{array}$ & $\begin{array}{l}\text {-Water } \\
\text { efficient } \\
\text { landscape }\end{array}$ & $\begin{array}{l}\text {-Mimicking } \\
\text { organic } \\
\text { function } \\
\text { "Biomimicry" }\end{array}$ & $\begin{array}{l}\text {-Net zero } \\
\text { water } \\
\text {-The } \\
\text { ecological } \\
\text { water flow }\end{array}$ \\
\hline & $\begin{array}{l}\text { Use and } \\
\text { store } \\
\text { Renewable, } \\
\text { Clean } \\
\text { Energies }\end{array}$ & $\begin{array}{l}\text {-Use solar } \\
\text { energy } \\
\text {-Stores solar } \\
\text { energy }\end{array}$ & $\begin{array}{l}\text {-Using } \\
\text { passive } \\
\text { cooling } \\
\text {-Using } \\
\text { passive } \\
\text { heating } \\
\text {-Use daylight } \\
\text {-Export } \\
\text { energy }\end{array}$ & $\begin{array}{l}\text {-On-site } \\
\text { renewable } \\
\text { energy } \\
\text {-Green power }\end{array}$ & $\begin{array}{l}\text {-Sunlight } \\
\text {-Natural light } \\
\text {-Mimicking } \\
\text { organic } \\
\text { function } \\
\text { "Biomimicry" }\end{array}$ & $\begin{array}{l}\text {-Net zero } \\
\text { energy use }\end{array}$ \\
\hline & $\begin{array}{l}\text { Recycling } \\
\text { Everything } \\
\text { or } \\
\text { Consuming } \\
\text { Its Own } \\
\text { Waste }\end{array}$ & $\begin{array}{l}\text {-Consumes } \\
\text { its own } \\
\text { waste } \\
\text {-Matches } \\
\text { nature's } \\
\text { cycles }\end{array}$ & $\begin{array}{l}\text {-Consumes } \\
\text { wastes } \\
\text {-Built of } \\
\text { recycled } \\
\text { materials } \\
\text {-Can be } \\
\text { recycled }\end{array}$ & $\begin{array}{l}\text {-Construction } \\
\text { waste } \\
\text { management } \\
\text {-Material } \\
\text { reuse } \\
\text {-Recycled } \\
\text { content } \\
\text {-Rapidly } \\
\text { renewable } \\
\text { materials }\end{array}$ & $\begin{array}{l}\text {-Mimicking } \\
\text { organic } \\
\text { function } \\
\text { "Biomimicry" }\end{array}$ & $\begin{array}{l}\text {-Conservation } \\
\text { and reuse of } \\
\text { materials }\end{array}$ \\
\hline
\end{tabular}


Table 2: $\quad$ Continued.

\begin{tabular}{|c|c|c|c|c|c|c|}
\hline Imperative & Dements & $\begin{array}{l}\text { The } \\
\text { Widerness } \\
\text { Cheoklist }\end{array}$ & $\begin{array}{c}\text { The Regen, } \\
\text { based } \\
\text { Checklist }\end{array}$ & LEDD & $\begin{array}{l}\text { Biophilic } \\
\text { design } \\
\text { Checklist }\end{array}$ & LBC \\
\hline \multirow{4}{*}{$\begin{array}{l}\text { Mimics } \\
\text { Natural } \\
\text { Systems In } \\
\text { The Way } \\
\text { They Act } \\
\text { For } \\
\text { Surviving }\end{array}$} & $\begin{array}{l}\text { Produces } \\
\text { Food }\end{array}$ & $\begin{array}{l}\text {-Produces } \\
\text { Its Own } \\
\text { Food }\end{array}$ & $\begin{array}{l}\text {-Produces } \\
\text { food }\end{array}$ & $\begin{array}{l}\text { - No } \\
\text { equivalent }\end{array}$ & $\begin{array}{l}\text { - No } \\
\text { equivalent }\end{array}$ & $\begin{array}{l}\text { - No } \\
\text { equivalent }\end{array}$ \\
\hline & $\begin{array}{l}\text { Maintains } \\
\text { Itself }\end{array}$ & $\begin{array}{l}\text {-Maintains } \\
\text { Itself }\end{array}$ & $\begin{array}{l}\text {-Maintains } \\
\text { Itself }\end{array}$ & $\begin{array}{l}\text { - No } \\
\text { equivalent }\end{array}$ & $\begin{array}{l}\text {-Mimicking } \\
\text { organic } \\
\text { function } \\
\text { "Biomimicry" }\end{array}$ & $\begin{array}{l}\text { - No } \\
\text { equivalent }\end{array}$ \\
\hline & $\begin{array}{l}\text { Minimize } \\
\text { Material } \\
\text { Use }\end{array}$ & $\begin{array}{l}\text {-No } \\
\text { equivalent }\end{array}$ & $\begin{array}{l}\text { - No } \\
\text { equivalent }\end{array}$ & $\begin{array}{l}\text { - No } \\
\text { equivalent }\end{array}$ & $\begin{array}{l}\text {-Mimicking } \\
\text { organic } \\
\text { function } \\
\text { "Biomimicry" }\end{array}$ & $\begin{array}{l}\text { - No } \\
\text { equivalent }\end{array}$ \\
\hline & $\begin{array}{l}\text { Use Local } \\
\text { Materials }\end{array}$ & $\begin{array}{l}\text {-No } \\
\text { equivalent }\end{array}$ & $\begin{array}{l}\text { - No } \\
\text { equivalent }\end{array}$ & $\begin{array}{l}\text {-Regional } \\
\text { materials }\end{array}$ & $\begin{array}{l}\text {-Mimicking } \\
\text { organic } \\
\text { function } \\
\text { "Biomimicry" }\end{array}$ & $\begin{array}{l}\text {-Using } \\
\text { appropriate } \\
\text { materials }\end{array}$ \\
\hline \multirow{2}{*}{$\begin{array}{l}\text { Protect } \\
\text { Widilie } \\
\text { Habitat }\end{array}$} & $\begin{array}{l}\text { Habitat } \\
\text { Exchange }\end{array}$ & $\begin{array}{l}\text {-Provides } \\
\text { wildlife } \\
\text { habitats }\end{array}$ & $\begin{array}{l}\text {-Provides } \\
\text { wildlife } \\
\text { habitats }\end{array}$ & $\begin{array}{l}\text {-Protect or } \\
\text { restore habitat }\end{array}$ & $\begin{array}{l}\text {-Landscape } \\
\text { ecology }\end{array}$ & $\begin{array}{l}\text {-Providing } \\
\text { habitat } \\
\text { exchange }\end{array}$ \\
\hline & $\begin{array}{l}\text { Limits of } \\
\text { Growth }\end{array}$ & $\begin{array}{l}\text {-No } \\
\text { equivalent }\end{array}$ & $\begin{array}{l}\text {-Serves as an } \\
\text { icon for } \\
\text { regeneration }\end{array}$ & $\begin{array}{l}\text {-Brownfield } \\
\text { development }\end{array}$ & $\begin{array}{l}\text { - No } \\
\text { equivalent }\end{array}$ & $\begin{array}{l}\text {-Limits to } \\
\text { growth }\end{array}$ \\
\hline $\begin{array}{l}\text { Protect } \\
\text { Human } \\
\text { Habitat }\end{array}$ & $\begin{array}{l}\text { Occupant } \\
\text { Satisfaction } \\
\text { and } \\
\text { Comfort }\end{array}$ & $\begin{array}{l}\text {-Provides } \\
\text { human } \\
\text { habitats }\end{array}$ & $\begin{array}{l}\text {-Provides } \\
\text { human } \\
\text { comfort }\end{array}$ & $\begin{array}{l}\text {-Increased } \\
\text { vent. } \\
\text { - } \\
\text { Controllability } \\
\text { of systems } \\
\text {-Thermal } \\
\text { comfort- } \\
\text { design } \\
\text {-Daylight and } \\
\text { views-daylight } \\
\text {-Daylight and } \\
\text { views- views } \\
\text {-Indoor } \\
\text { chemical and } \\
\text { pollutant } \\
\text { source control }\end{array}$ & $\begin{array}{l}\text { - No } \\
\text { equivalent }\end{array}$ & $\begin{array}{l}\text {-Human scale } \\
+ \text { human } \\
\text { places } \\
\text {-Democracy + } \\
\text { Social Justice }\end{array}$ \\
\hline
\end{tabular}


Table 2: $\quad$ Continued.

\begin{tabular}{|c|c|c|c|c|c|c|}
\hline Imperative & Mements & $\begin{array}{l}\text { The } \\
\text { Wilderness } \\
\text { Checklist }\end{array}$ & $\begin{array}{c}\text { The Regen. } \\
\text { based } \\
\text { Checklist }\end{array}$ & LDDD & $\begin{array}{l}\text { Biophilice } \\
\text { design } \\
\text { Checklist }\end{array}$ & $\mathrm{LBC}$ \\
\hline \multirow[t]{3}{*}{$\begin{array}{l}\text { Be A Good } \\
\text { Neighbor }\end{array}$} & $\begin{array}{l}\text { Sense of } \\
\text { Place }\end{array}$ & $\begin{array}{l}\text {-Moderates } \\
\text { local } \\
\text { weather }\end{array}$ & $\begin{array}{l}\text {-A good } \\
\text { neighbor } \\
\text {-Serves as an } \\
\text { icon for } \\
\text { regeneration } \\
\text {-Moderate } \\
\text { local weather }\end{array}$ & $\begin{array}{l}\text {-Innovation } \\
\text { and design } \\
\text { process } \\
\text {-Regional } \\
\text { priority }\end{array}$ & $\begin{array}{l}\text {-Geographical } \\
\text { connection } \\
\text { place } \\
\text {-Historical } \\
\text { connection } \\
\text { place } \\
\text {-Cultural } \\
\text { connection } \\
\text { place } \\
\text {-Ecological } \\
\text { connection } \\
\text { place } \\
\text {-Indigenous } \\
\text { materials } \\
\text {-Landscape } \\
\text { orientation } \\
\text {-Landscape } \\
\text { ecology } \\
\text {-Integrating } \\
\text { culture and } \\
\text { ecology } \\
\text {-Sense or } \\
\text { spirit of place } \\
\text {-Avoiding } \\
\text { placelessness } \\
\text {-Landscape } \\
\text { feature that } \\
\text { define } \\
\text { building form }\end{array}$ & $\begin{array}{l}\text {-Rights to } \\
\text { nature }\end{array}$ \\
\hline & $\begin{array}{l}\text { Creates } \\
\text { Silence }\end{array}$ & $\begin{array}{l}\text {-Creates } \\
\text { silence }\end{array}$ & $\begin{array}{l}\text {-A good } \\
\text { neighbor }\end{array}$ & $\begin{array}{l}\text {-Innovation } \\
\text { and design } \\
\text { process } \\
\text {-Regional } \\
\text { priority }\end{array}$ & $\begin{array}{l}\text { - No } \\
\text { equivalent }\end{array}$ & $\begin{array}{l}\text {-Urban } \\
\text { agriculture }\end{array}$ \\
\hline & $\begin{array}{l}\text { Be } \\
\text { Beautiful } \\
\text { And Have } \\
\text { A Nature } \\
\text { Inspiration }\end{array}$ & -Is beautiful & -Is beautiful & $\begin{array}{l}\text {-Innovation } \\
\text { and design } \\
\text { process }\end{array}$ & $\begin{array}{l}\text {-Natural } \\
\text { shapes and } \\
\text { forms } \\
\text {-Natural } \\
\text { patterns and } \\
\text { process } \\
\text {-Evolved } \\
\text { relation to } \\
\text { nature }\end{array}$ & $\begin{array}{l}\text {-Beauty + } \\
\text { spirit } \\
\text {-Inspiration } \\
+ \text { education }\end{array}$ \\
\hline
\end{tabular}

A building to be listed as a bio-eco regenerative should first maintain itself, this could be achieved by mimicking natural organisms function (Biomimicry), this credit is found in the original checklist by wells but unfortunately hasn't be developed in the most known applicable sustainable rating system, it could 
indirectly fall under the credit of innovation. Creating silence is also a very important credit for a building to be listed as a bio-eco regenerative design but it couldn't be defined without the post occupancy evaluation as well it is not listed in the set of credits available in the most known sustainable rating systems.

Recently, human priorities have changed so that sustainability and regenerative design must take a high priority through all sectors of society as well as the governmental sectors. A quantitative rating systems and check lists could be applied to a technological worldview and are inappropriate for living system understanding and adaptation. Principle based understanding is essential for living systems because each place and being is unique and requires a level of understanding that acknowledges and identifies this uniqueness or essence. A qualitative assessment tool in form of a checklist as a guideline to encourage regenerative design could be applied in living building strategies by providing a post occupancy evaluation samples to measure and evaluate the degree of comfort and the applicability of regenerative strategies in each building.

\section{References}

[1] IUCN/UNEP/WWF, 1991, Caring for the Earth: A Strategy for Sustainable Living, Gland, Switzerland, p10

[2] Kellert S. R., 2005, Building for Life: Designing and Understanding the Human-Nature Connection, Island press, USA

[3] Wells M., 1982, Gentle Architecture, McGraw-Hill, UK

[4] Gabe J., 2005, A triumph of irrationality: How architectural history, fashion trends and modern-day economic paradigms discourage the design of ecologically sustainable architecture, University of Auckland

[5] Hodges N., A, 2006, Regenerative Design Theory and Practice: Demonstration of the Integrated Framework in a Resort Development at Mountain Lake, VA

[6] Wendt A., June 2009, The Living Building Challenge Can It Really Change the World?, The Leading Newsletter on Environmentally Responsible Design and Construction, Volume 18, Number 6

[7] "Biomimicry in Architecture" [Web page] posted by Levitt, 2008, http://www.worldchanging.com/local/seattle/archives/008117.html

(December 16th 2012)

[8] "Beyond Leed and Bream: The Living Building Challenge - Part 1" [Web page] posted by Leedham A., 2011: http://archinect.com/blog /article/23655771/beyond-leed-and-bream-the-living-building-challengepart-1 (Accessed (December 1th 2012))

[9] "LEED Green Associate Study Guide" 2009 edition: http://www2.tec.ilstu.edu/

[10] McClure W., R., Bartuska T., J., 2007, The Built Environment: A Collaborative Inquiry Into Design and Planning, John Wiley and Sons, New Jersey 